UDC 541.13.544.65

\title{
CO-ELECTRODEPOSITION OF THIN Mo-S FILMS
}

\author{
S.F.Jafarova \\ M.Nagiyev Institute of Catalysis and Inorganic Chemistry NAS of Azerbaijan \\ ceferova.samira@list.ru
}

Received 03.06.2019

Accepted 04.11.2019

\begin{abstract}
The co-electrodeposition process of Mo with S from aqueous electrolytes was investigated. It has been determined the range of potentials of co-electrodeposition of Mo with S by plotting the cyclic polarization curves on a Pt-electrode. When studying the obtained thin films by the methods of the X-ray phase and Raman spectroscopic (Raman scattering) analyses, it was found that the peaks on the curve correspond to the formed $\mathrm{MoS}_{2}$ compound.
\end{abstract}

Keywords: $\mathrm{MoS}_{2}$, polarization, thin films, electrodeposition, semiconductors.

doi

Thin films are widely used as various functional coatings to increase strength, corrosion resistance, improve the magnetic and electrical properties of materials applied in aviation and space technology, mechanical engineering, medicine, energetics, and digital microelectronics. Recently, studies on the getting thin films by the electrochemical method from various electrolytes have been intensively tested. The use of thin-film materials reduces the material consumption of devices for various purposes. Thin-film semiconductors with sulfur are of great interest for the photoelectrochemical and photochemical conversion of solar energy.

Dichalcogenides of transition metals are layered materials with strong in-plane and weak out-of-plane interactions, allowing them to exfoliate into two-dimensional thin sheets. Although they have been studied for decades, recent advances in the characterization of nanoscale materials and device manufacturing have opened up new possibilities for them in nano- and optoelectronics.

The authors of the work [1] have electrochemically deposited $\mathrm{MoS}_{2}$ films using ionic liquids. This technique is especially useful for the inexpensive, environmentally friendly synthesis of molybdenum chalcogenides and mixed metal chalcogenides. The electrodeposited lowlayer $\mathrm{MoS}_{2}$ showed characteristic fluorescence properties, demonstrating that these materials have optoelectronic properties of ultra-thin $\mathrm{MoS}_{2}$ film, preferably, for applications such as photodetectors and light-emitting devices. In addition, this method allows an optional setting of the film thickness and demonstrates high photoluminescent activity during decreasing the number of layers.

$\mathrm{MoS}_{2}$ can be electrodeposited from different media - from molten salts, ionic liquids, non-aqueous and aqueous solutions [2]. The magnitude of the potential at which $\mathrm{MoS}_{2}$ is deposited depends on the medium from which the deposition occurs. Deposits obtained at more negative potentials are rich in molybdenum, and therefore essentially metallic. The authors of [2] found that the temperature of the electrolyte significantly affects the growth of deposits since a higher temperature leads to faster growth rates of crystals, as well as to adhesion of the films. At high values of $\mathrm{pH}$, the deposition rate is relatively low, while at lower $\mathrm{pH}$ values, mixed - phase films of $\mathrm{MoS}_{2}$ are obtained. It was also found that the electrodeposition of $\mathrm{MoS}_{2}$ from high-temperature molten salt permits to obtain clearly defined crystals. The photoelectrochemical behavior of $\mathrm{MoS}_{2}$ electrodes in neutral and alkaline electrolytes showed that the $\mathrm{MoS}_{2}$ semiconductor reacts with water, which leads to its decomposition into metal ions and molecular sulfur.

Nanostructured thin films of molybdenum disulfide have been deposited on various substrates in the electrolyzer at a constant current from an aqueous electrolyte containing molybdate and sulfide ions by the authors of [3]. An- 
nealing the deposited thin films at higher temperatures in the range of $450-700^{\circ} \mathrm{C}$, turns the deposited amorphous films into a nanocrystalline structure. UV and visible spectra confirmed the presence of Mo-S in the deposited films.

In studies [4, 5], thin films of molybdenum sulfide $\left(\mathrm{MoS}_{x}\right)$ have been obtained on substrates of indium-tin-oxide/polyethylene naphthalate (ITO/PEN) by a pulse electrochemical deposition method. The results showed that thin $\operatorname{MoS}_{x}$ films are uniformly deposited on flexible ITO/PEN substrates and are active catalysts for triiodide reduction. $\operatorname{MoS}_{x}$ thin films are obtained at roomtemperature and atmospheric-pressure in a simple and quick way. This is an important practical contribution to the production of flexible, inexpensive thin-film solar cells based on plastic substrates.

According to the literature, of the electrochemical deposition of molybdenum with sulfur have been studied differently. To obtain accurate results in this area, the aim of this work is to study the kinetics of the co-electrodeposition process of molybdenum with sulfur from an aqueous solution and to determine the range of potentials in which they are deposited. As you know, to obtain thin films of semiconductor materials by co-deposition, the first need to do is to study the kinetics and mechanism of the electroreduction process of the components separately. This was investigated by us in $[6,7]$.

\section{Experimental part}

The process of electrochemical deposition of molybdenum with sulfur from aqueous electrolytes was carried out as follows. Solutions containing molybdenum and sulfur are

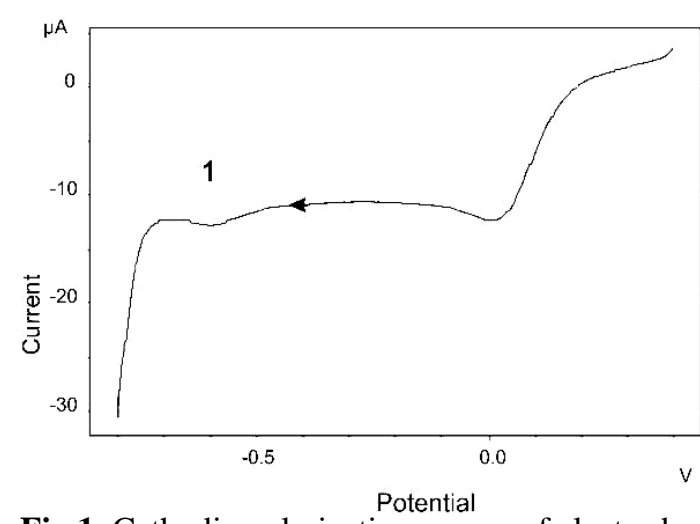

prepared separately. The molybdenum solution contains $1 \mathrm{M} \mathrm{Na} 2 \mathrm{MoO}_{4} \cdot 2 \mathrm{H}_{2} \mathrm{O}$, and sulfur solution $0.1 \mathrm{M} \mathrm{Na}_{2} \mathrm{SO}_{3}$.

Polarization curves were plotted using an IVIUMSTAT Electrochemical Interface potentiostat. An electrochemical three-electrode glass cell was used. A Pt-electrode with an area of $0.4 \mathrm{~cm}^{2}$ was used as a working electrode. The silver chloride electrode served as the reference electrode, and the platinum plate with an area of $4 \mathrm{~cm}^{2}$ served as the auxiliary electrode.

The phase composition of the obtained thin layers was determined in the "D2 Phazer" X-ray phase analyzer of Bruker Company $\left(\mathrm{CuK}_{\alpha}\right.$-radiation $\mathrm{Ni}$ filter).

Raman scattering of Mo-S samples (Raman spectroscopy) was studied using Niodim YAG laser beams in a device of 3D Confocal Raman System, Micro-NanoScale Microspectroscopy, Nanofinder 30 (Tokyo Instr., Japan) at $\lambda=532 \mathrm{~nm}$.

\section{Results and their discussion}

The electrochemical reduction processes of molybdenum [6] and sulfur [7] were studied separately to determine the potential region, deep reduction, and the nature of polarization for carrying out joint electrochemical deposition, as described above.

As is seen from the figure, the electrochemical reduction process of molybdate ions carries out within $0.2-(-0.7) \mathrm{V}$ potential interval (Figure 1, curve 1), while of sulphit ions in the range of $0.4-(-0.3) \mathrm{V}$ potential (Figure.1, curve 2) it was determined that the electrochemical reduction of both ions is accompanied by electrochemical polarization.

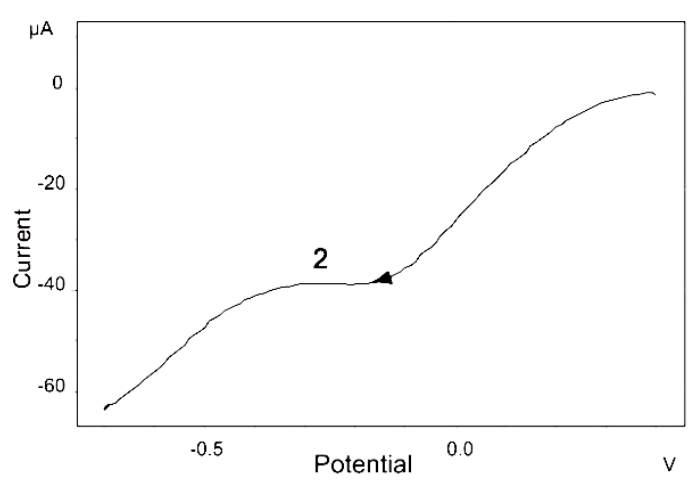

Fig.1. Cathodic polarization curves of electrodeposition process of molybdate ions $(1)$ and sulphit ions (2) from aqueous electrolytes on the Pt electrode. Electrolyte (M): $1-1 \mathrm{Na}_{2} \mathrm{MoO}_{4} \cdot 2 \mathrm{H}_{2} \mathrm{O} ; 2-0.1$ $\mathrm{Na}_{2} \mathrm{SO}_{3} ; T=298 \mathrm{~K}, E_{\mathrm{V}}=0.02 \mathrm{~V} / \mathrm{s}$. 


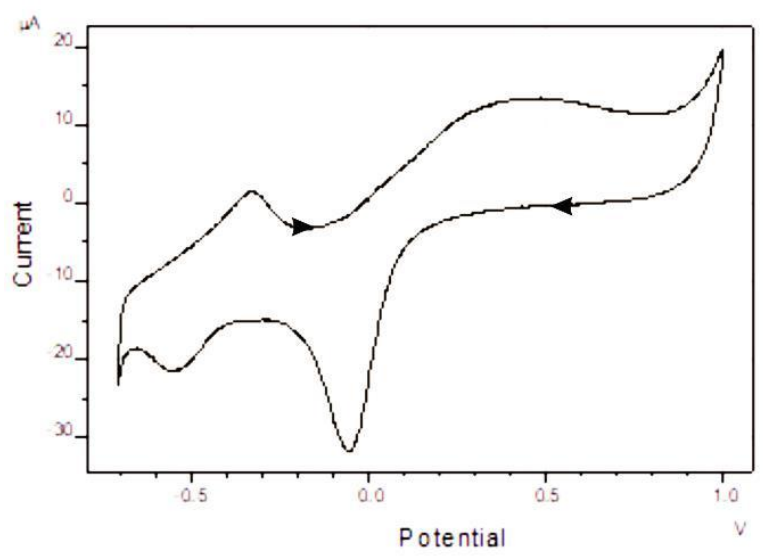

Fig.2. Cyclic polarization curve of electrodeposition process of molybdenum with sulfur from aqueous electrolytes on $\mathrm{Pt}$ electrode. Electrolyte (M): $1 \mathrm{Na}_{2} \mathrm{MoO}_{4} \cdot 2 \mathrm{H}_{2} \mathrm{O}+0.1 \mathrm{Na}_{2} \mathrm{SO}_{3} ; T=298 \mathrm{~K}$, $E_{\mathrm{V}}=0.02 \mathrm{~V} / \mathrm{s}$.

Figure 2 shows the cyclic polarization curve of the electrochemical co-deposition of molybdenum with sulfur. As can be seen from the figure, the electrochemical deposition occurs in stages within potential intervals of $0.3-$ $(-0.65) \mathrm{V}$ on the Pt-electrode according to the following reaction:

$$
\mathrm{Mo}^{4+}+2 \mathrm{~S}^{2-} \rightarrow \mathrm{MoS}_{2}
$$

Starting from the $0.3 \mathrm{~V}$ potential, on the electrode surface, the electrodeposition of sulfur occurs till $-0.3 \mathrm{~V}$. Then, in the range of potentials $-0.3-(-0.65) \mathrm{V}$, the co-electrodeposition of molybdenum with sulfur begins reaction (1). In this case, the surface of the electrode is covered with a black layer. The continuation of the process is presented on the anode branch of the cyclic curve. The peak obtained at the potential of $-0.3 \mathrm{~V}$ pertains to the dissolution of the obtained molybdenum compound with sulfur, but after 0.2 to $1.0 \mathrm{~V}$, it relates to the dissolution of sulfur [8, 9]. The studying electrodeposition process up to $-0.7 \mathrm{~V}$ is related to observing the release of hydrogen after this potential value.

Thin films obtained on the surface of a platinum electrode were studied using various analysis methods. Figure 3 shows the X-ray diffraction pattern of the deposited Mo-S films. As can be seen from the figure, in the X-ray diffraction pattern, there are peaks corresponding to the $\mathrm{MoS}_{2}$ compound. This is also confirmed by Raman scattering. Since the active shift of Raman scattering for molybdenum disulfide is recorded in the range of $350-450 \mathrm{~cm}^{-1}$. Here, the peaks located on the surface at 350 and 380 $\mathrm{cm}^{-1}$ correspond to sulfur atoms fluctuating in one direction, and the peak located at $420 \mathrm{~cm}^{-1}$ is related to the molybdenum atom.

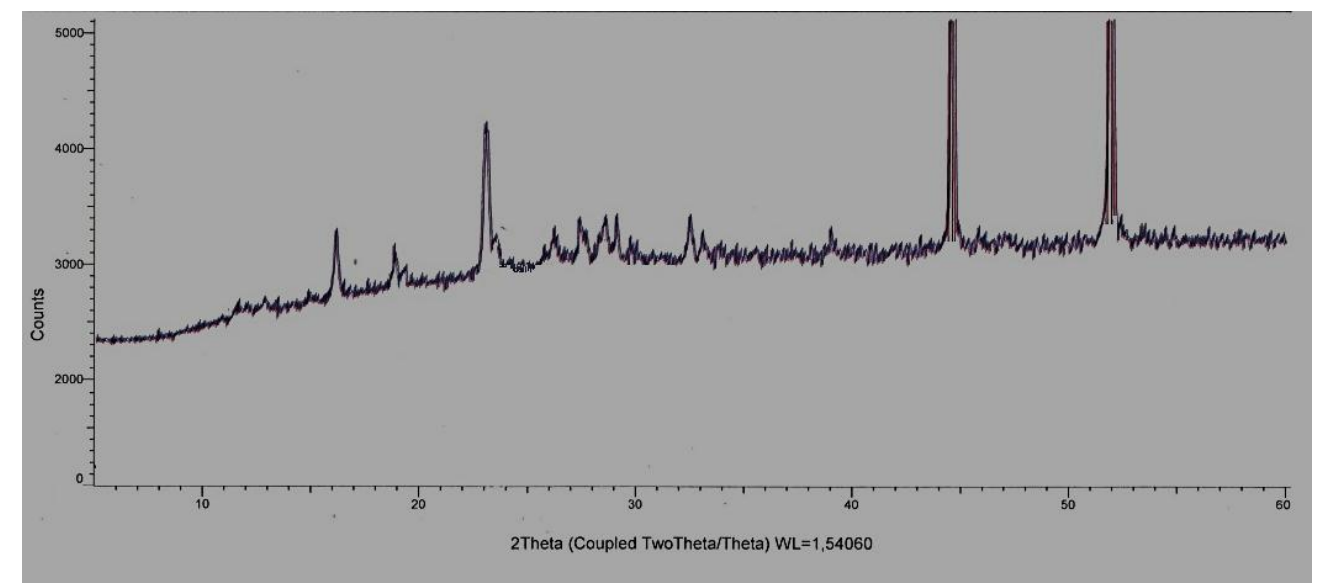

Fig. 3. X-ray diffraction pattern for $\mathrm{MoS}_{2}$ compound. Electrolyte (M): $1 \mathrm{Na}_{2} \mathrm{MoO}_{4} \cdot 2 \mathrm{H}_{2} \mathrm{O}+$ $0.1 \mathrm{Na}_{2} \mathrm{SO}_{3} ; T=298 \mathrm{~K}, E_{\mathrm{V}}=0,02 \mathrm{~V} / \mathrm{s}$. 


\section{Conclusions}

The voltammetric method was used to study the process of co-deposition of Mo-S on Pt-electrodes from aqueous electrolytes. It was determined that co-deposition occurs in the potential region of $-0.3-(-0.65) \mathrm{V}$. Also, using Xray phase analysis and Raman scattering, it was found that noticeable peaks confirm the codeposition process and the obtaining the $\mathrm{MoS}_{2}$ compound resulting from this co-deposition.

\section{References}

1. Murugesan S., Akkineni A., Chou B.P., Glaz M.S., Vanden Bout D.A., Stevenson K.J. Room Temperature Electrodeposition of Molybdenum Sulphide for Catalytic and Photoluminescence Applications. ACS Nano. 2013. V. 7. No 9. P. 8199-8205. doi:10.1021/nn4036624

2. Aliyev A.Sh., Elrouby M., Cafarova S.F. Electrochemical synthesis of molybdenum sulphide semiconductor. Materials Science in Semiconductor Processing. 2015. V. 32. P. 31-39.

3. Ghosh S.K., Srivastava C., Nath S., Celis J.P. Simple Formation of Nanostructured Molybdenum Disulfide Thin Films by Electrodeposition. International Journal of Electrochemistry. 2013. V. 2013. Article ID 138419, 7 pages, http://dx.doi.org/10.1155/2013/138419
4. Cheng C.K., Hsieh C.K. Electrochemical deposition of molybdenum sulphide thin films on conductive plastic substrates as platinum-free flexible counter electrodes for dye-sensitized solar cells. Thin Solid Films. 2015. V. 584. P. 52-60

5. Lin C.-H., Tsai C.-H., Tseng F.-G., Ma C.-C. M., Wu H.-C., Hsieh C.-K. Three-dimensional vertically aligned hybrid nanoarchitecture of twodimensional molybdenum disulphide nanosheets anchored on directly grown one-dimensional carbon nanotubes for use as a counter electrode in dyesensitized solar cells. J. Alloys and Compounds. 2017. V. 692. P. 941-949. doi.org/10.1016/ j.jallcom.2016.09.149.

6. Cafarova S.F., Aliyev A.Sh., Elrouby M., Soltanova N.Sh., Tagiyev D.B. Studying the electrochemical deposition process of molybdenum from aqueous solution of molybdate ions. J. Electrochem. Sci. Eng. 2015. V. 5. No 4. P. 231-235; doi: $10.5599 /$ jese. 219 .

7. Cəfərova S.F., Məcidzadə V.A., Oliyev A.Ş. Tiosulfat ionlarının molibden elektrodda elektroreduksiya prosesinin todqiqi. Chemical Problems. 2017. № 1. S. 72-76.

8. Majidzade V.A., Cafarova S.F., Aliyev A.Sh., Nuriyev Y.A., Farhatova N.B., Tagiyev D.B. Electrochemical deposition of thin semiconductive Mo-S films. Azerb. Chem. Journ. 2019. № 1. P. 63-13.

9. Majidzade V.A., Cafarova S.F., Aliyev A.Sh., Tagiyev D.B. Influence of various factorson the composition of electrodeposited thin films Mo-S. Azerb. Chem. Journ. 2018. No 3. P. 6-10.

\section{Mo-S NAZIK TəBəQӘLəRINIIN BİRGə ELEKTROÇÖKDÜRÜLMəSİ}

\section{S.F.Cəfərova}

Təqdim edilən işdə elektrolitlərin suda məhlullarından molibden və kükürdün birgə elektrokimyəvi çökmə prosesi öyrənilmişdir. Pt elektrodu üzərində tsiklik polyarizasiya əyrilərinin çəkilməsi ilə Mo və S-ün birgə elektrokimyəvi çökmə prosesi üçün potensial sahəsi təyin edilmişdir. Alınan nazik təbəqələrin müxtəlif müasir metodlarla öyrənilməsi zamanı, müəyyən edilmişdir ki, rentgen faza və Raman səpələnməsi (kombinassion səpələnmə) analizləri nəticəsində əldə olunan piklər $\mathrm{MoS}_{2}$ birləşməsinə uyğundur.

Açar sözlar: $\mathrm{MoS}_{2}$, polyarizasiya, nazik təbəqalər, elektrokimyavi çökdürülmə, yarımkeçirici.

\section{СОВМЕСТНОЕ ЭЛЕКТРООСАЖДЕНИЕ ТОНКИХ ПЛЕНОК Мо-S}

\section{С.Ф.Джафарова}

В данной работе изучено совместное электроосаждение молибдена с серой из водных электролитов. Снятием циклических поляризационных кривых на Pt-электроде определена область потенциалов совместного электроосаждения Мо c S. При исследовании полученных тонких пленок различными современными методами установлено, что пики, полученные в результате рентгенофазовых и Раман спектроскопических (комбинационное рассеяние) анализах соответствуют получению соединения $\mathrm{MoS}_{2}$.

Ключевые слова: $\mathrm{MoS}_{2}$, поляризачия, тонкие пленки, электроосаждение, полупроводники. 